\title{
PENGARUH LEADER MEMBER EXCHANGE (LMX) DAN KEADILAN PROSEDURAL TERHADAP KOMITMEN ORGANISASI GURU SMK NEGERI DI JAKARTA UTARA
}

\author{
Hetiny Muthia Rahmy*
}

\begin{abstract}
The purpose of this research is to know the effect of Leader Member Exchange (LMX) and procedural justice toward State Vocational School teacher's organizational commitment in North Jakarta. The research was conducted using survey method with quantitative approach and path analysis technique. The population of this research is 186 teachers. Research samples as much as 127 teachers were selected using simple random sampling technique. The data was obtained through questionnaires and analyzed using path analysis techniques. Based on the results of the data analysis in this research, it is concluded that: (1) the Leader Member Exchange (LMX) has a positive direct effect to organizational commitment; (2) the procedural justice has a positive direct effect to organizational commitment; (3) the Leader Member Exchange (LMX) has a positive direct effect to procedural justice. Therefore, the organizational commitment can be improved through the enhancement of Leader Member Exchange (LMX) and procedural justice.
\end{abstract}

Keywords: Leader Member Exchange (LMX), Procedural Justice and Organizational Commitment

\section{PENDAHULUAN}

Sekolah sebagai lembaga pendidikan formal merupakan sarana dalam rangka pencapaian tujuan pendidikan nasional. Hal ini termuat dalam UndangUndang RI Nomor 20 Tahun 2003 tentang Sistem Pendidikan Nasional yang menjelaskan fungsi dan tujuan pendidikan nasional. Permasalahan yang masih sering timbul dalam dunia pendidikan yaitu terkait rendahnya mutu pendidikan di Indonesia. Berdasarkan hasil Programme for International Student Assessment (PISA) terbaru tahun 2015 menunjukkan bahwa kemampuan matematika, sains, dan membaca anak Indonesia menduduki posisi ke-69 dari 76 negara peserta. Sedangkan dari hasil studi TIMSS (Trends in International Mathematics and Science Study), menunjukkan bahwa siswa Indonesia berada pada peringkat 36 dari 49 negara dalam hal melakukan prosedur ilmiah. Dalam 10 tahun terakhir ini hasil PISA dan TIMSS masih berjalan di tempat.

Pemerintah dan lembaga pendidikan harus lebih fokus kepada kualitas pendidikan saat ini. Pencapaian hasil pendidikan yang masih kurang memuaskan terutama dalam lingkup sekolah, menjadi tanggungjawab Kepala sekolah dan guru. Guru merupakan unsur pendidikan yang memiliki hubungan sangat dekat dengan siswa dan menentukan keberhasilan dalam mencapai tujuan pendidikan. Dalam

\footnotetext{
* Guru kimia SMA di Superstar Education Kelapa Gading
} 
Pasal 7 Undang-Undang Republik Indonesia Nomor 14 Tahun 2005 tentang Guru dan Dosen disebutkan bahwa profesi guru merupakan pekerjaan khusus yang dilaksanakan berdasarkan prinsip memiliki komitmen untuk meningkatkan mutu pendidikan, keimanan, ketakwaan, dan akhlak mulia.

Di sekolah, guru merupakan tenaga profesional yang sudah selayaknya mampu menjalankan tugas dan kebijakan sekolah, serta memiliki komitmen terhadap sekolah. Menurut Fred Luthans, komitmen organisasi digambarkan sebagai keinginan yang kuat untuk tetap menjadi anggota dari suatu organisasi tertentu, kesediaan untuk berusaha semaksimal mungkin untuk kepentingan organisasi, dan kepercayaan serta penerimaan nilai dan tujuan dari organisasi.

Dalam kenyataannya, guru juga tidak terlepas dari berbagai permasalahan. Namun permasalahan yang timbul salah satunya justru disebabkan oleh perilaku guru yang kurang komitmen terhadap pekerjannya. Beberapa perilaku guru yang memiliki komitmen rendah misalnya hadir di sekolah tetapi tidak mengajar, mengerjakan tugas lain yang tidak terkait dengan kegiatan mengajar, datang terlambat, dan pulang lebih awal. Tingkat komitmen guru yang rendah pada sebuah organisasi juga berdampak terhadap pencitraan publik suatu organisasi, sehingga akan mengalami kesulitan dalam mempertahankan kualitas sekolah yang sudah lama dibangun. Rendahnya komitmen seorang guru dalam berorganisasi muncul karena dipicu oleh beberapa faktor, diantaranya karena Leader Member Exchange (LMX) yang rendah dan kurangnya rasa keadilan prosedural yang ada di sekolah.

Dalam sebuah organisasi dengan tingkat kualitas LMX yang tinggi, bawahan akan mendapatkan perhatian dan pendampingan secara khusus dari pemimpinnya. Bawahan akan merasa diterima dalam organisasi tersebut dan akan merasa puas terhadap pekerjaan mereka, sehingga mereka akan bekerja dengan sepenuh hati dan berusaha secara maksimal untuk mencapai tujuan organisasi. Selain Leader Member Exchange (LMX), penilaian keadilan dalam organisasi mempengaruhi komitmen guru. Setiap orang pasti menginginkan untuk diperlakuan secara adil. Ketika para guru diperlakukan dengan adil, mereka akan mempunyai komitmen yang tinggi untuk keberhasilan organisasi bahkan dalam kondisi sesulit apapun. Oleh karena itu, peneliti merasa perlu mengkaji tentang "Pengaruh Leader Member Exchange (LMX) dan Keadilan Prosedural terhadap Komitmen Organisasi Guru SMK Negeri di Jakarta Utara."

\section{Komitmen Organisasi}

Colquitt, et al. (2015:64), mendefinisikan komitmen organisasi sebagai berikut, "organizational commitment is defined as the desire on the part of an employee to remain a member of the organization. Organizational commitment influences whether an employee stays a member of the organization (is retained) or leaves to pursue another job (turns over)". Komitmen organisasi adalah digambarkan sebagai keinginan dari seorang pegawai untuk tetap menjadi bagian dari organisasi. Komitmen organisasi memengaruhi apakah seorang pegawai akan tetap menjadi anggota dari organisasi atau meninggalkan untuk mengejar pekerjaan lain. Komitmen terhadap organisasi 
artinya lebih dari sekedar keanggotaan formal, karena meliputi sikap menyukai organisasi dan kesediaan untuk berususaha semaksimal mungkin demi kepentingan organisasi untuk pencapaian tujuan organisai. Dalam hal ini, komitmen organisasi mencakup unsur loyalitas terhadap organisasi, keterlibatan dalam pekerjaan, dan identifikasi terhadap nilai-nilai dan tujuan organisasi.

Kemudian Griffin dan Moorhead (2014: 74) mendefinisikan komitmen organisasi sebagai berikut, "organizational commitment, sometimes called job commitment, reflects an individual's identification with and attachment to the organization". Komitmen organisasi, kadang-kadang disebut juga dengan komitmen terhadap pekerjaan, yaitu sikap yang mencerminkan identifikasi individu terhadap pekerjaannya dan keterikatannya terhadap organisasi. Pendapat senada diungkapkan oleh Newstrom (2015: 236), "organizational commitment or employee loyalty is the degree to which an employee identifies with the organization and wants to continue actively participating in it". Komitmen organisasi atau loyalitas pegawai adalah derajat dimana seorang pegawai mengenali organisasi dan keinginan untuk melanjutkan secara aktif berpartisipasi di dalamnya.

Sikap seperti ini merupakan faktor yang sangat mendukung keberhasilan organisasi. Dengan pemahaman yang baik akan pekerjaannya dan adanya keterikatan yang tinggi pada setiap anggota organisasi maka mereka akan mampu bekerja maksimal dan tidak hanya sebatas menyelesaikan tugas saja, tetapi mampu melakukan yang terbaik demi organisasinya.

Lebih lanjut Fred Luthans (2011: 147) menyatakan beberapa definisi mengenai komitmen organisasi, diantaranya sebagai berikut, "as an attitude, organizational commitment is most often defined as (1) a strong desire to remain a member of a particular organization; (2) a willingness to exert high levels of effort on behalf of the organization; and (3) a definite belief in, and acceptance of, the values and goals of the organization. In other words, this is an attitude reflecting employees' loyalty to their organization and is an ongoing process through which organizational participants express their concern for the organization and its continued success and well-being". Sebagai sikap, komitmen organisasi adalah yang paling sering didefinisikan sebagai (1) keinginan yang kuat untuk tetap menjadi anggota organisasi tertentu; (2) kemauan untuk mengerahkan usaha tingkat tinggi atas nama organisasi; dan (3) keyakinan dan penerimaan atas nilai-nilai dan tujuan dari organisasi. Dengan kata lain, komitmen organisasi adalah sikap yang mencerminkan loyalitas pegawai kepada organisasi mereka dan adanya proses yang berkelanjutan di mana peserta organisasi mengungkapkan keprihatinan mereka terhadap organisasi dan juga terhadap kesuksesan dan kesejahteraan organisasi.

Kemudian menurut Jennifer George \& Gareth Jones (2012:88), "organizational commitment relates to feelings and beliefs about the employing organization as a whole". Komitmen organisasi berhubungan dengan perasaan dan keyakinan mengenai penggunaan organisasi secara keseluruhan. Lebih Lanjut Robbins dan Judge (2015:102), menyatakan bahwa, "in organizational commitment, an employee identifies with a particular organization and its goals and wishes to remain a member". 
Komitmen organisasi adalah perasaan emosi, keterlibatan dan identifikasi seorang pegawai terhadap organisasi tertentu.

Newstrom (2015:236) membedakan komitmen organisasi menjadi tiga bentuk, "it is useful to distinguish between three forms of organizational commitment. Affective commitment is a positive emotional state in which employees want to exert effort and choose to remain with the organization. Normative commitment is the choice to stay attached because of strong cultural or familial ethics that drive them to do so. They believe they ought to be committed because of others' belief systems and their own internalized norms and feelings of obligation. Continuance commitment encourages employees to stay because of their high investments in the organization (time and effort) and the economic and social losesses they would incur if they left". Ini bermanfaat untuk membedakan tiga bentuk dari komitmen organisasi. Komitmen afektif adalah emosi positif yang menunjukkan pegawai mau untuk berusaha dan memilih untuk tetap pada posisi dengan organisasi. Komitmen normatif adalah pilihan untuk tetap melekat karena kebudayaan yang kuat atau rasa kekeluargaan yang mendorong mereka untuk melakukan hal tersebut. Mereka percaya bahwa mereka harus berkomitmen karena sistem kepercayaan dan norma internal yang dimiliki serta perasaan wajib. Komitmen berkelanjutan mendorong pegawai untuk tetap pada organisasi karena investasi yang tinggi pada organisasi (waktu dan usaha) dan keadaan ekonomi serta kerugian sosial yang akan datang jika mereka meninggalkan organisasi.

Berdasarkan uraian di atas, maka dapat disintesiskan komitmen organisasi adalah keinginan pegawai untuk tetap bertahan dalam organisasi, dengan indikator: (1) kesetiaan kepada organisasi, (2) keterikatan untuk tetap menjadi bagian organisasi, (3) menerima tujuan dan nilai-nilai organisasi, dan (4) mematuhi peraturan organisasi.

\section{Leader-Member Exchange (LMX)}

Menurut Yukl, LMX (2010:235) didefinisikan sebagai berikut, "Leader Member Exchange (LMX) theory describes the role-making processes between a leader and each individual subordinate and the exchange relationship that develops over time. LMX theory was formerly called the vertical dyad linkage theory because of its focus on reciprocal influence processes within vertical dyads composed of one person who has direct authority over another person".Teori LMX menjelaskan proses pembuatan peran antara pemimpin dan setiap individu bawahan dan hubungan pertukaran yang berkembang dari waktu ke waktu. Teori LMX sebelumnya disebut teori hubungan diad vertikal (dua arah) karena fokus pada proses pengaruh timbal balik dalam diad vertikal yang terdiri dari satu orang yang memiliki kewenangan langsung atas orang lain.

Model LMX menekankan pentingnya hubungan variatif antara pemimpin dengan masing-masing bawahanya. Tiap pasangan pemimpin dan bawahan dinamakan dengan diad vertikal. Istilah diad vertikal menunjuk kepada hubungan antara seorang pemimpin dan seorang bawahan saja. Dasar pemikiran teori diad vertikal adalah bahwa para pemimpin biasanya menetapkan sebuah hubungan 
yang istimewa dengan sejumlah bawahan yang sangat dipercaya yaitu kelompok dalam (in-group). Hubungan pertukaran yang dibangun dengan para bawahan yang selebihnya kelompok luar (out-group) secara berbeda.

Kemudian Luthans (2011:422) mengartikan LMX sebagai berikut, "LMX theory says that leaders treat individual followers differently. In particular, leaders and their associates develop dyadic (two-person) relationships that affect the behavior of both. For example, associates who are committed and who expend a lot of effort for the unit are rewarded with more of the leader's positional resources (for example, information, confidence, and concern) than those who do not display these behaviors". Teori LMX mengatakan bahwa pemimpin memperlakukan bawahan dengan cara yang berbeda-beda. Secara khusus, para pemimpin dan bawahannya mengembangkan hubungan yang mempengaruhi perilaku keduanya (hubungan diadik). Sebagai contoh, pegawai yang berkomitmen dan yang melakukan banyak usaha untuk lembaga akan dihargai oleh pemimpin misalnya diberikan informasi, kepercayaan, dan kepedulian daripada pegawai yang tidak berkomitmen untuk lembaga.

Artinya, teori kepemimpinan yang banyak dipelajari sebagian besar mengasumsikan bahwa pemimpin memperlakukan semua bawahan mereka dengan cara yang sama. Dalam kenyataannya, pemimpin bisa bertindak dengan sangat berbeda kepada orang yang satu dengan yang lainnya. Dengan kata lain, pemimpin cenderung memiliki orang-orang kesayangan dalam suatu organisasi. Biasanya pemimpin cenderung memilih anggota kelompok karena mereka memiliki berbagai karakteristik kepribadian dan sikap yang mirip dengan pemimpin tersebut atau karena tingkat kompetensi yang lebih tinggi daripada bawahan yang lainnya. Kelompok kesayangan akan mendapatkan kepercayaan dan perhatian yang lebih besar dari pemimpin, bahkan mereka mungkin menerima hak istimewa tertentu. LMX berfokus pada hubungan diadik (dua arah) antara pemimpin dan bawahannya untuk meningkatkan kesuksesan organisasi dengan menciptakan hubungan yang positif antara pimpinan dengan bawahannya.

Lebih lanjut Gibson( 2012:334) menjelaskan LMX sebagai berikut "the LMX approach suggests that leaders classify subordinates into in-group members and out-group members. In-group members share a common bond and value system, and they interact with the leader. Out-group members have less in common with the leader and don't share much with her". Pendekatan LMX menunjukkan bahwa para pemimpin mengklasifikasikan bawahan menjadi anggota kelompok dalam dan anggota kelompok luar. Anggota kelompok dalam berbagi ikatan dan sistem nilai yang umum, dan berinteraksi dengan pemimpin. Anggota kelompok luar kurang memiliki kesamaan dengan pemimpin dan tidak banyak berbagi dengan pemimpin.

Pendapat tersebut diperkuat oleh Schermerhorn (2010:316), seperti dijelaskan berikut ini, "an LMX scale assesses the degree to which leaders and followers have mutual respect for one another's capabilities, feel a deepening sense of mutual trust, and have a strong sense of obligation to one another. Taken together, these dimensions tend to establish the extent to which followers will be a part of the leader's "in-group" or "outgroup." In-group followers tend to function as assistants, lieutenants, or advisers and to 
have higher-quality personalized exchanges with the leader than do out-group followers. The out-group followers tend to emphasize more formalized job requirements, and a relatively low level of mutual influence exists between leaders and out-group followers. The more personalized in-group exchanges typically involve a leader's emphasis on assignments to interesting tasks, delegation of important responsibilities, information sharing, and participation in the leader's decisions, as well as special benefits, such as personal support, approval, and favorable work schedules". LMX menilai sejauh mana para pemimpin dan pengikut saling menghormati kemampuan satu sama lain, rasa saling percaya, dan memiliki rasa kewajiban yang kuat satu sama lain. Secara bersama-sama, dimensi ini cenderung untuk menetapkan sejauh mana pengikut akan menjadi bagian dari kelompok dalam (in-group) atau kelompok luar (out-group) pemimpin. Pengikut kelompok dalam cenderung berfungsi sebagai asisten, letnan, atau penasehat dan memiliki kualitas tinggi dalam pertukaran dengan pemimpin daripada pengikut kelompok luar. Para pengikut kelompok luar cenderung menekankan pekerjaan yang lebih formal dan relatif memiliki pengaruh yang rendah anatara pemimpin dan pengikut kelompok luar. Kelompok dalam biasanya melibatkan penekanan seorang pemimpin pada penugasan bawahan untuk tugas yang menarik, pendelegasian tanggung jawab yang penting, berbagi informasi, dan partisipasi dalam keputusan pemimpin, serta manfaat khusus, seperti dukungan pribadi, persetujuan, dan jadwal kerja yang menguntungkan.

Kemudian Kreitner dan Kinicki (2010:490) berpendapat bahwa, "the LMX model is based on the assumption that leader develop unique one-to-one relationships with each of the people reporting to them". Model LMX adalah sesuatu yang berdasarkan asumsi bahwa pemimpin mengembangkan hubungan yang unik dengan satu per satu pegawai dari orang yang memberitakan kepada mereka.

Berdasarkan konsep-konsep di atas, maka dapat disintesiskan bahwa Leader Member Exchange (LMX) adalah hubungan timbal balik antara pemimpin dan bawahan yang bertujuan untuk memajukan organisasi dengan indikator: (1) berkonstribusi pada tugas; (2) loyalitas; (3) keinginan untuk saling mendukung; (4) rasa hormat.

\section{Keadilan Prosedural}

Pengertian keadilan prosedural yang dipaparkan Schermerhorn, et.al. (2010:117) menyatakan bahwa, "procedural justice is the degree to which the rules and procedures specified by policies are properly followed in all cases to which they are applied". Keadilan prosedural adalah kadar atau derajat dari tiap peraturan dan prosedur yang ditetapkan dalam kebijakan untuk bisa diikuti dan dilaksanakan dengan baik dalam berbagai keadaan. Beragam aspirasi dan banyaknya keterlibatan para pihak dalam pengambilan keputusan, menjadikan suatu kebijakan menjadi luwes dan dapat merangkul semua kepentingan dalam organisasi.

Kemudian pengertian keadilan prosedural menurut Gibson, Ivancevich, Donnelly dan Konopaske (2009:148) menyatakan bahwa, "procedural justice refers to the perceived equity or fairness of the organization's processes and procedures used to make 
resource and allocation decisions. That is, employees are concerned with the fairness of decision making in all areas of work, including decisions related to compensation, performance appraisal, training, and work group assignments". Keadilan prosedural mengacu pada keadilan yang dirasakan atau kewajaran pada proses dan prosedur organisasi yang digunakan untuk membuat dan mengalokasikan sumber daya dan keputusan. Artinya, bahwa pegawai yang bersangkutan merasakan adanya kewajaran dalam pengambilan keputusan di semua bidang pekerjaan, termasuk keputusan yang terkait dengan kompensasi, penilaian kinerja, pelatihan, dan tugas kelompok kerja.

Kemudian Kreitner dan Kinicki (2010:221) mendefinisikan bahwa, "procedural justice is defined as the perceived fariness of the process and procedures used to make allocation decision". Keadilan prosedural didefinisikan sebagai keadilan yang dirasakan dari proses dan prosedur yang digunakan untuk membuat keputusan pendistribusian. Pernyataan tersebut diperkuat oleh pendapat Don Hellriegel \& John W. Slocum (2011:46) yang menyatakan bahwa, "procedural justice refers to the perceived fairness of the rules, guidelines, and processes for making decisions". Keadilan prosedural mengacu pada keadilan yang dirasakan dari aturan, pedoman, dan proses untuk membuat keputusan.

Lalu menurut Mc Shane dan Von Glinow (2008:151), menyatakan bahwa "procedural justice refers to fairness of the procedures used to decide the distribution of resources". Keadilan prosedural merupakan keadilan yang mengacu pada prosedur yang digunakan untuk menentukan pendistribusian sumber daya. Menurut Colquit (2013:227) bahwa, "procedural justice reflects the perceived fairness of decision-making processes. Procedural justice is fostered when authorities adhere to rules of fair process". Keadilan prosedural menggambarkan keadilan yang dirasakan dari proses pengambilan keputusan. Keadilan prosedural mendapatkan tempatnya untuk berkembang ketika otoritas mematuhi aturan proses yang adil. Prosedur yang berlaku dapat dikatakan adil bagi seluruh anggota organisasi jika memenuhi beberapa kriteria yang mencerminkan dan merepresentasikan kepentingan bagi semua pihak.

Berdasarkan konsep-konsep yang telah diuraikan di atas, dapat disintesiskan bahwa keadilan prosedural adalah keadilan atau kewajaran yang dirasakan oleh semua anggota organisasi dari proses dan prosedur yang digunakan untuk membuat keputusan dengan indikator: (1) keterlibatan bawahan, (2) perlakuan yang tidak memihak, (3) konsisten dalam penerapan aturan-aturan, (4) keterbukaan, (5) informasi yang bersifat netral.

\section{METODE}

Penelitian ini dilaksanakan menggunakan pendekatan kuantitatif dengan metode survei dengan teknik analisis jalur (Path Analysis). Dimana penelitian ini menguji pengaruh langsung pada setiap variabel penelitian. Adapun variabel yang dimaksud adalah Leader Member Exchange $\left(\mathrm{X}_{1}\right)$, keadilan prosedural $\left(\mathrm{X}_{2}\right)$, dan 
komitmen organisasi $\left(\mathrm{X}_{3}\right)$. Sampel dalam penelitian ini diambil dengan menggunakan teknik Simple Random Sampling, yaitu cara pengambilan sampel yang dilakukan secara acak sederhana. Teknik ini untuk memperoleh sampel dari jumlah sample frame. Jumlah sampel yang diambil sebanyak 127 orang guru SMK Negeri di Jakarta Utara dari 186 orang populasi terjangkau. Teknik pengumpulan data dilakukan dengan menggunakan kuesioner dengan skala penelitian Likert (Likert rating scale). Setelah dilakukan analisis deskriptif dilanjutkan dengan uji persyaratan analisis berupa uji normalitas, uji linearitas data dan keberartian regresi. Uji hipotesis yang dilakukan menggunakan teknik analisis jalur (path analysis).

\section{HASIL DAN PEMBAHASAN}

\section{Pengaruh Leader Member Exchange (LMX) terhadap Komitmen Organisasi}

Dari hasil pengujian hipotesis pertama dapat disimpulkan bahwa terdapat pengaruh langsung positif Leader Member Exchange (LMX) terhadap komitmen organisasi dengan nilai koefisien korelasi sebesar 0,403 dan nilai koefisien jalur sebesar 0,324. Hal ini menujukkan bahwa Leader Member Exchange (LMX) dapat meningkatkan komitmen organisasi guru SMK Negeri Jakarta Utara.

Hasil penelitian ini senada dengan pendapat beberapa ahli diantaranya menurut John B. Miner (2005:270) yang mengatakan bahwa, "LMX can operate to exert a strong positive influence on goal commitment. This influence occurs for high-LMX people, but it disappers completely when the LMX is low". LMX dapat memberikan pengaruh positif yang kuat pada komitmen yang sudah menjadi tujuan. Pengaruh ini terjadi bagi guru-guru yang memiliki kualitas LMX yang tinggi, namun menghilang sepenuhnya ketika kualitas LMX rendah.

Hubungan pertukaran antara Kepala sekolah dengan guru yang tinggi berpengaruh terhadap kuatnya komitmen organisasi guru di sekolah, sehingga tujuan-tujuan sekolah akan tercapai. Guru yang memiliki kualitas LMX yang tinggi dengan kepala sekolah, memiliki hubungan yang sangat baik dengan Kepala sekolah. Sedangkan guru yang memiliki kualitas LMX yang rendah dengan kepala sekolah, memiliki hubungan yang kurang baik dengan Kepala sekolah. Guru yang memiliki kualitas LMX tinggi merupakan guru yang dapat diandalkan dalam berpartisipasi dan memberikan usaha lebih dari yang ditetapkan di gambaran pekerjaan (job description) guru.

Kemudian Yukl (2010:238) berpendapat bahwa, "LMX was usually correlated with more role clarity, higher satisfaction, stronger organizational commitment and better subordinate performance". LMX memiliki keterkaitan dengan peran yang besar, kepuasan yang lebih tinggi, komitmen organisasi yang lebih kuat, dan kinerja guru yang lebih baik. Terkait dengan pengaruh Leader Member Exchange (LMX), Robbins dan Judge (2013:374) mengatakan bahwa, "Leader-member exchange was associated strongly with followers' commitment to the organization when leaders were seen as embodying the values and identity of the organization". Hubungan pertukaran Kepala 
sekolah dan guru berpengaruh kuat dengan komitmen guru terhadap organisasi sekolah ketika Kepala sekolah telah terlihat mewujudkan nilai dan identitas dari organisasi sekolah.

Selanjutnya Kreitner dan Kinicki (2010:490) mengemukakan bahwa, “A positive leader-member exchange was positively associated with job satisfaction, job performance, commitment to organizational change, trust between managers and employees, work climate, willingness to help coworkers, and satisfaction with leadership". Hubungan pertukaran Kepala sekolah dan guru yang tinggi berpengaruh positif dengan kepuasan kerja, kinerja, komitmen terhadap perubahan organisasi, kepercayaan antara Kepala sekolah dan guru, iklim kerja, kesediaan untuk membantu rekan kerja, dan kepuasan dengan Kepala sekolah.

Berdasarkan penelitian, kualitas hubungan LMX yang tinggi antara Kepala sekolah dengan guru menunjukkan bahwa ada komunikasi yang baik antara Kepala sekolah dengan guru, loyalitas guru kepada Kepala sekolah maupun kepada sekolah tempat guru mengajar yang tinggi, Kepala sekolah dan guru sama-sama berkontribusi untuk mencapai tujuan sekolah, serta adanya rasa hormat dan saling mendukung antara Kepala sekolah dan guru. Tingginya kualitas LMX yang terjalin antara Kepala sekolah dengan guru menyebabkan terbentuknya komitmen organsasi guru yang kuat terhadap sekolah tempat guru mengajar.

\section{Pengaruh Keadilan Prosedural terhadap Komitmen Organisasi}

Dari hasil pengujian hipotesis kedua dapat disimpukan bahwa terdapat pengaruh langsung positif keadilan prosedural terhadap komitmen organisasi dengan nilai koefisien korelasi sebesar 0,377 dan nilai koefisien jalur sebesar 0,289. Ini memberikan makna keadilan prosedural berpengaruh langsung positif terhadap komitmen organisasi.

Hasil penelitian ini senada dengan pendapat beberapa ahli di antaranya menurut Gibson, et al. (2012:149) menjelaskan sebagai berikut, "procedural justice has been shown to have a positive impact on a number of affective and behavioral reactions at the workplace. In other words, when employees perceive high levels of procedural justice with the organization's resource and allocation decisions, they are more likely to: Be committed to the organization; Be intrinsically motivated; Stay with the organization; Engage in organizational citizenship behaviors; Trust their supervisors; Apply great effort to their work; and Perform their job well". Keadilan prosedural telah terbukti memiliki dampak positif pada sejumlah reaksi afektif dan perilaku di tempat kerja (sekolah). Dengan kata lain, ketika guru merasakan tingkat tinggi dari keadilan prosedural dengan sumber daya dan alokasi keputusan organisasi, guru lebih cenderung untuk: berkomitmen kepada sekolah; menjadi termotivasi secara intrinsik; tetap bertahan di sekolah; terlibat dalam perilaku kewargaan organisasi; percaya terhadap Kepala sekolah; melakukan upaya besar untuk pekerjaan; dan melakukan pekerjaan dengan sebaik mungkin.

Prosedur yang dilakukan oleh Kepala sekolah dalam mengambil keputusan dapat dikatakan adil bagi seluruh guru jika memenuhi kriteria yang 
mencerminkan dan merepresentasikan kepentingan bagi semua guru tanpa memihak pada satu atau kelompok guru tertentu. Prosedur yang adil juga memiliki mekanisme untuk banding dalam rangka memperbaiki keputusan atau kebijakan Kepala sekolah yang salah. Ketika guru merasa telah diperlakukan adil dalam setiap prosedur yang dilakukan oleh Kepala sekolah, komitmen organisasi guru tentu menjadi tinggi.

Kemudian Luthans (2011:173) menjelaskan bahwa, "overall justice climate (procedural, informational, and interpersonal) and found it related to various work outcomes (commitment, satisfaction, and citizenship behaviors)". Keseluruhan iklim keadilan (prosedural, informasional, dan interpersonal) dan berpengaruh terhadap berbagai hasil kerja (komitmen, kepuasan, dan perilaku kewargaan.

Sekolah yang memiliki iklim keadilan prosedural yang tinggi menunjukkan bahwa prosedur yang berlaku dalam pengambilan keputusan sudah jelas dan jujur tanpa ada yang ditutup-tutupi demi kemajuan dan kepentingan sekolah. Keputusan dan kebijakan yang diambil Kepala sekolah akan menjadi lebih tepat karena berdasarkan pada prosedur pengambilan keputusan dengan menggunakan informasi yang akurat. Maka dengan demikian, perlakuan dari Kepala sekolah yang sangat menghargai aspirasi dan prestasi guru akan sangat mempengaruhi komitmen organisasi guru menjadi lebih kuat.

Lebih lanjut Kreitner dan Kinicki (2010:222) menjelaskan sebagai berikut, "all three forms of justice were positively correlated with job satisfaction, organizational commitment, organizational citinzenship behaviors, and employees' trust, and negatively with employees' withdrawal cognitions and turnover". Ketiga bentuk dari keadilan berpengaruh positif dengan kepuasan kerja, komitmen organisasi, OCB dan kepercayaan guru dan berpengaruh negatif dengan penarikan diri guru dan pengunduran diri guru. Keadilan prosedural harus bersifat netral dan bebas dari bias, yang tidak terpengaruh oleh kepentingan pribadi guru atau kepentingan pihak-pihak tertentu. Sehingga prosedur yang digunakan dapat mempertimbangkan dan mewakili kepentingan dari seluruh guru. Keadilan prosedural yang tinggi yang dirasakan guru di sekolah menyebabkan menguatnya komitmen organisasi guru terhadap sekolah sehingga guru akan merasa nyaman di sekolah dan tidak akan keluar/mengundurkan diri dari sekolah.

\section{Pengaruh Leader Member Exchange (LMX) terhadap Keadilan Prosedural}

Dari hasil pengujian hipotesis ketiga dapat disimpulkan bahwa terdapat pengaruh langsung positif LMX terhadap keadilan prosedural dengan nilai koefisien korelasi sebesar 0,272 dan nilai koefisien jalur sebesar 0,272. Ini memberikan makna LMX berpengaruh langsung positif terhadap keadilan prosedural.

Hasil penelitian ini senada dengan pendapat beberapa ahli di antaranya menurut Colquit et.al. (2013:213), "procedural justice was a stronger predictor of satisfaction with supervision, overall job satisfaction, and organizational commitment than distributive justice". Keadilan prosedural menjadi pengaruh yang lebih kuat dengan kepuasan dengan adanya supervisi dari Kepala Sekolah, keseluruhan kepuasan 
kerja, dan komitmen organisasi, daripada keadilan distributif. Dengan adanya supervisi, maka akan terjadi hubungan timbal balik antara Kepala sekolah dan guru yang semakin kuat, sehingga LMX berpengaruh positif terhadap keadilan prosedural yang dirasakan oleh guru.

Kemudian Fred Luthans (2011:431) menjelaskan sebagai berikut, "transformational leadership mediated by leader-member exchange produced effects on followers' performance and organizational citizenship behaviors (OCBs). Also, were found to be moderated by perceptions of procedural justice and trust". Kepemimpinan transformasional yang dilengkapi dengan Leader Member Exchage Kepala sekolah berpengaruh terhadap kinerja guru dan Organizational Citizenship Behaviors (OCB). Selain itu juga berpengaruh terhadap persepsi dari keadilan prosedural dan kepercayaan yang dirasakan guru. Kualitas LMX yang tinggi antara Kepala sekolah dengan guru menunjukkan adanya hubungan timbal balik, rasa saling percaya, dan rasa saling menghormati antara Kepala sekolah dengan guru. Hal inilah yang menjadi dasar Kepala sekolah dalam mengambil keputusan sehingga guru merasa diperlakukan secara adil.

Leow dan Khong (2009:161) dalam penelitiannnya menyebutkan, "the said integration facilitates the examination of the direct effect of LMX and organisational justice and the effect to three variables organization commitment". Dikatakan fasilitas integrasi pengujian secara langsung LMX berpengaruh terhadap keadilan organisasi yang dirasakan guru dan berpengaruh ketiga variabel komitmen organisasi.

Hubungan yang baik antara Kepala sekolah dengan guru yang terwujud dengan tingginya kualitas LMX, menyebabkan keadilan prosedural yang dirasakan guru meningkat. Sebab pemahaman Kepala sekolah mengenai karakteristik guru yang berbeda-beda dijadikan dasar untuk pertimbangan dalam pengambilan keputusan sesuai dengan prosedur yang berlaku. Hal inilah yang membuat guru merasa diperlakukan secara adil sehingga guru memiliki komitmen yang tinggi terhadap sekolah.

\section{PENUTUP}

Kesimpulan: (1) Leader Member Exchange (LMX) berpengaruh langsung positif terhadap komitmen organisasi. Artinya, peningkatan Leader Member Exchange (LMX) mengakibatkan peningkatan komitmen organisasi guru SMK Negeri di Jakarta Utara. (2) Keadilan Prosedural berpengaruh langsung positif terhadap komitmen organisasi. Artinya, ketepatan keadilan prosedural mengakibatkan peningkatan komitmen organisasi guru SMK Negeri di Jakarta Utara. (3) Leader Member Exchange (LMX) berpengaruh langsung positif terhadap keadilan prosedural. Artinya, peningkatan Leader Member Exchange (LMX) mengakibatkan ketepatan keadilan prosedural guru SMK Negeri di Jakarta Utara.

Saran : (1) Bagi Dinas Pendidikan Jakarta Utara hendaknya lebih intensif melakukan pelatihan mengenai kepemimpinan, manajemen sekolah, maupun pelatihan terkait 
peningkatan kompetensi-kompetensi Kepala sekolah sehingga dapat meningkatkan kualitas Leader Member Exchange (LMX) Kepala sekolah dengan guru, dan menguatkan rasa keadilan prosedural, agar setiap guru di sekolah yang bersangkutan memiliki komitmen organisasi yang tinggi. (2) Bagi Kepala Sekolah diharapkan mampu meningkatakan kompetensinya sebagai pemimpin di sekolah. Selain itu, Kepala sekolah hendaknya dapat mendelegasikan tugas atau wewenang kepada guru secara merata. Kepala sekolah juga harus memperlakukan guru secara adil dalam semua hal. Terakhir, Kepala sekolah sebaiknya melibatkan guru dalam pengambilan keputusan dan membuat keputusan yang tidak hanya memihak pada sekelompok guru saja sehingga tercipta hubungan Leader Member Exchange (LMX) yang tinggi dan keadilan prosedural yang kuat. Dengan demikian komitmen organisasi dari setiap guru yang dipimpinnya menjadi meningkat. (3) Bagi para guru SMK Negeri di Jakarta Utara diharapkan dapat menjalin komunikasi yang baik dengan Kepala sekolah. Selain itu, guru hendaknya mampu bekerja sama dengan kepala sekolah sebagai pemimpin dan sesama guru sebagai tim kerja. Guru juga sebaiknya aktif berpartisipasi dalam semua rapat ataupun kegiatan sekolah sehingga tercipta hubungan Leader Member Exchange yang tinggi dan keadilan prosedural. Dengan demikian komitmen organisasi guru akan meningkat. (4) Bagi para peneliti lain agar penelitian ini dapat dijadikan rujukan dalam penelitian lanjutan berikutnya. 


\section{DAFTAR RUJUKAN}

Colquitt, Jason A., LePine, Jeffrey A., Wesson, Michael J., Organizational Behavior, New York: McGraw Hill, 2013.

George, Jennifer M., Jones, Gareth R., Understanding and Managing Organizational Behavior 6ed, New Jersey: Prentice Hall, 2012.

Gibson, James L., et.al., Organizations: Behavior, Structure, Processes, New York: McGraw-Hill Companies, Inc., 2012.

Griffin and Moorhead, Organizational Behavior: Managing People and Organizations, Eleventh Edition, Canada: Cengage Learning, 2014.

Hellriegel, Don and John W. Slocum, Organizational Behavior 13e, South-Western: Cengange Learning, 2011.

Ivancevich, Konopaske, Robert., Metteson, Michael T., Organizational Behavior Management 8ed, New York: McGraw-Hill, 2013.

Kreitner and Kinicki, Organizational Behavior, Ninth Edition, New York: McGraw-Hill International Edition, 2010.

Luthans, Fred., Organizational Behavior; an Evidence-Based Approach, New York: McGraw Hill Irwin, 2011.

McShane, Steven L., Glinow, Mary Ann Von., Organizational Behavior Emerging Realities for the Workplace Revolution, New York: Mc Graw Hill, 2008.

Miner, John B., Organizational Behavior, New York: M E.Sharpe, Inc., 2005.

Mullins, Laurie J., Management and Organisational Behaviour, London: Prentice Hall, 2005.

Newstrom, John W., Organizational Behavior: Human Behavior at Work, Fourteenth Edition New York: McGraw-Hill Education, 2015.

Robbins, Stephen P., Mary Coulter, Management 11ed, New Jersey: Prentice Hall, 2012

Robbins, Stephen P., Judge, Timothy., Organizational Behavior 15ed, New Jersey: Pearson Education, Inc., 2013.

Schermerhorn, John R., Hunt, James G., Osborn, Richard N., Uhl-Bien, Mary, Organizational Behavior 11ed, USA: John Wiley \& Sons, Inc.,2010

Yukl, Gary, Leadership in Organizations Global Edition, $7^{\text {th }}$ Edition, New Jersey: Pearson Education, Inc., 2010. 